\title{
HUBUNGAN ANTARA DUKUNGAN SOSIAL DENGAN RESILIENSI PADA PENYINTAS BANJIR ROB TAMBAK LOROK
}

\author{
Syahria Nur Jannah dan Rohmatun \\ Fakultas Psikologi Universitas Islam Sultan Agung Semarang, Jl. Kaligawe km 4 Semarang \\ Email: rohmatun@unissula.ac.id
}

\begin{abstract}
Abstrak
Penelitian ini bertujuan untuk mengetahui hubungan antara dukungan sosial dengan resiliensi pada penyintas banjir rob Tambak Lorok. Penelitian ini menggunakan metode kuantitatif. Populasi dalam penelitian ini berjumlah 308 orang. Teknik sampling yang digunakan dalam penelitian ini adalah purposive sampling, dengan jumlah sampel 80 orang berusia antara 20-70 tahun di kampung Tambak Lorok Semarang. Pengambilan data dalam penelitian ini menggunakan dua skala yaitu skala dukungan sosial dan skala resiliensi. Hasil penelitian diuji menggunakan korelasi product moment dari. Skala dukungan sosial berjumlah 29 aitem dengan rentang daya beda antara 0,313-0,619 dan koefisien reliabilitas sebesar 0,908. Skala resiliensi berjumlah 27 aitem dengan rentang daya beda antara 0,258-0,539 dan koefisien reliabilitas sebesar 0,802. Hasil uji hipotesis memperoleh $r x y=0,428$ dengan taraf signifikansi $p=0,000(p<0,01)$. Hal ini menunjukkan bahwa terdapat hubungan yang positif atau signifikan antara dukungan sosial dengan resiliensi. Sehingga dapat disimpulkan bahwa semakin besar dukungan sosial yang diterima para penyintas banjir rob Tamba Lorok maka semakin baik pula resiliensinya. Begitu juga sebaliknya, semakin kecil dukungan sosial yang diterima maka semakin rendah pula resiliensinya.Sumbangan efektif dukungan sosial terhadap resiliensi sebesar 18,3\%. Maka dapat diketahui setidaknya ada $81,7 \%$ faktor lain yang tidak diteliti oleh peneliti dan dapat berpengaruh pada resiliensi.
\end{abstract}

Kata Kunci : Dukungan Sosial, Resiliensi.

\section{RELATIONSHIP BETWEEN SOCIAL SUPPORT AND RESILIENCE AMONG TIDAL WAVE SURVIVORS IN TAMBAK LOROK}

\begin{abstract}
This study aims to determine the relationship between social support and resilience of the survivors of the tidal flood Tambak Lorok. This research used quantitative methods. Populations in this research were 308 people. The sampling technique used in this research is purposive sampling, with 80 sampel aged 20-70 years in the village Tambak Lorok Semarang. Results of the study were tested using theproduct moment correlation. The data were gathered using two scales, namely : social support and resilience. Social support scale totaling 29 item with different power ranges between 0.313 to 0.619 and the reliability coefficient of 0.908 . Resilience scale amounted to 27 item with different power ranges between 0.258 to 0.539 and the reliability coefficient of 0.802 . Hypothesis test results obtained $r x y=0.428$ with a significance level of $p=0.000(p<0.01)$. This shows that there is a positive and significant relationship between social support and resilience. It can be concluded that the greater the social support received by the survivors of the tidal flood Tambak Lorok the better the resilience. Likewise, the smaller the social support received then the lower the resilience. Effective contribution of social support to the resilience of $18.3 \%$. It is known there are at least $81.7 \%$ of other factors that were not studied by researchers and can affect resilience.
\end{abstract}

Keywords : Social Support, Resilience. 


\section{PENDAHULUAN}

Indonesia merupakan negara kepulauan yang terletak diantara tiga lempengan benua yang hiperaktif. Indonesia berada pada posisi yang rentan akan terjadinya bencana alam. Menurut LIPIUNESCO/ISDR (2006) bencana alam yang seringkali dirasakan oleh oleh warga Indonesia adalah badai tropis, longsor, kekeringan, banjir, gunung meletus, gempa bumi hingga tsunami (Fara, 2012). Salah satu fenomena bajir yang terjadi di Indonesia adalah banjir rob. Daerah-daerah yang sering terjadi dikota pantai seperti pada daerah Jakarta dan Semarang (Chandra K \& Supriharjo, 2013). Sedangkan menurut Kodoatie dalam BBC Indonesia (2007) mengungkapkan bahwa beberapa daerah dikawasan pesisir kota Semarang setiap tahunnya terjadi penurunan tanahnya hingga mencapai $10 \mathrm{~cm}$. Akibatnya kondisi ini dapat menambah luasnya wilayah yang terdampak intrusi air laut atau rob (Miladan, 2009).

Banjir rob merupakan banjir yang terjadi akibat peluapan air laut atau air sungai. Hal yang dapat menjadi penyebab terjadinya banjir rob yang dikarenakan meluapnya air yang berlebihan disuatu tempat yang dikarenakan curah hujan yang tinggi, peluapan dari air sungai, atau bahkan pecahnya bendungan sungai (Somantri, 2008). Dibyosaputro (1984) menjelaskan bahwa selain disebabkan oleh meluapnya air sungai dan kelebihan curah hujan. Banjir juga disebabkan oleh fluktuasi permukaan air laut, khususnya dataran aluvial pantai dan unit-unit gemorfologi. Seperti pada daerah rawa, rawa belakang, dataran banjir, pertemuan antara sungai dengan dataran aluvial. Fluktuasi air laut inilah yang disebut sebagai rob (Somantri, 2008). Elevation Zone Map of Semarang City memprediksikan bahwa pada tahun 2013 amblesan tanah akan semakin memperparah tergenangnya beberapa wilayah di kawasan Pesisir Kota Semarang diakibatkan kenaikan paras permukaan air laut (Miladan, 2009), termasuk kawasan Tambak Lorok yang merupakan salah satu kawasan pesisir yang terletak di Kelurahan Tanjungmas Semarang yang akan terkena genangan air akibat naiknnya rob. (Natalia \& Alie, 2014).

Banjir rob seringkali dianggap sebagai hal yang sudah biasa untuk sebagian masyarakat pesisir khususnya bagi yang tempat tinggalnya berbatasan dengan laut. Tetapi jika kondisi ini terus dibiarkan, tidak menuntup kemungkinan rob akan menjadi salah satu faktor kerentanan masyarakat pesisir. Hal tersebut disebabkan rob yang terjadi bukan hanya sudah menggerus bibir pantai, namun lebih dari itu, yaitu telah masuk ke pemukiman pesisir dan bahkan telah menenggelamkan rumah warga (Ariviyanti \& Pradoto, 2014).

Pakar Hidrologi Fakultas Teknik Undip Semarang menyatakan bahwa kondisi normal kampung Tambak Lorok terus mengalami penurunan tanah 20-30 sentimeter setiap tahun. Dalam lima tahun terakhir tanggul hancur dan belum ada perbaikan. Masalah yang dirasakan masyarakat Tambak Lorok tersebut disebabkan karena selalu terkena banjir air pasang (banjir rob). Ditambah lagi oleh pengaruh banjir yang disebabkan oleh hujan (Herusansono, 2012).

Hewlet (1982) mengatakan bahwa banjir merupakan aliran atau genangan air yang bukan hanya memunculkan kerugian ekonomi tetapi juga menyebabkan kehilangan jiwa (Somantri, 2008). Banjir rob yang terjadi tentunya merupakan salah satu peristiwa alam yang dapat menyisakan penderitaan bagi orang-orang yang mengalaminya. Menurut Yayasan Pulih \& JICA (2006) hal yang dialami para penyintas bencana alam antara lain luka-luka, kematian, penyakit, tubuh menjadi lemah dan dari aspek psikologis akan menimbulkan perasaan cemas, takut, merasa bersalah, marah, sedih, dan kehilangan. Adapun dalam aspek kognitif, orang yang menjadi penyintas dapat menjadi kalut dan bingung (Fara, 2012). Sedangkan Ehreinreich (2001) memaparkan bahwa semakin tinggi tingkat keparahan bencana

2 P-ISSN 1907-8455 
dan tingkat kengerian pengalaman yang dialami maka semakin besar pula efek psikologis yang dirasakan oleh penyintas (Taufiq, Susanty, Titi, \& Nurlina, 2014).

Banjir rob yang terjadi di kawasan Tambak Lorok sebagai daerah rawan terjadinya peristiwa alam menuntut komunitas yang menjadi korban untuk dapat beradaptasi dan tetap bertahan dalam menghadapi kesulitan yang dihadapi. Hodgkinson (1998) mengungkapkan bahwa bencana alam menantang wilayah, lingkungan, dan komunitas penyintas untuk kembali memegang kendali kehidupan dan bangkit atas masa depannya. Kemampuan seseorang yang menjadikan individu dapat bertahan, bangkit, dan menyesuaikan dengan kondisi menyulitkan tersebut disebut sebagai resiliensi (Lestari, 2007).

Berbagai penderitaan yang disebabkan oleh peristiwa bencana alam, dialami oleh individu yang berada ditempat sekitar. Individu yang mengalaminya harus dapat memegang kendali atas kejadian traumatis agar dapat terus melanjutkan hidup. Bangkit dari suatu kondisi-kondisi kritis atau sulit bukanlah suatu hal yang mudah untuk dilakukan. Individu akan melalui sebuah proses panjang untuk agar dapat kembali pada kondisi baik sebelum mengalami suatu kesengsaraan.

Boss (Mawarpury dan Mirza, 2017), menyatakan bahwa toleransi terhadap ketidakpastian yang panjang, serta kemampuan melakukan adaptasi, bertahan dan tumbuh dari kesengsaraan disebut dengan resiliensi. Mawarpury dan Mirza, (2017), menyimpulkan definisi resiliensi dari berbagai teori, lebih menekankan pada proses adaptasi positif yang disertai dengan kemampuan untuk bangkit kembali dari pengalaman buruk dan menyakitkan yang dialami oleh individu. Resiliensi merupakan konsep yang pada mulanya dikembangkan dalam konteks psikopatologi perkembangkan dan didasarkan pada perspektif ekologi, koping dan stress.

Newcomb (Widuri, 2012) mengartikan resiliensi sebagai sebuah mekanisme perlindungan yang memodifikasi respon pada kondisi-kondisi berisiko pada titik kritis sepanjang kehidupan individu. Reivich \& Shatte (2002) mengatakan bahwa individu yang memiliki resiliensi dapat mengatasi berbagai permasalahan kehidupan dengan cara mereka masing-masing, pada situasi sulit yang tidak dapat dihindari sekalipun. Sedangkan Holaday berpendapat bahwa individu dianggap sebagai memiliki resiliensi ketika mereka mampu secara cepat kembali kepada kondisi sebelum trauma dan terlihat kebal dari berbagai peristiwa-peristiwa kehidupan yang negatif (Tampi, Kumaat, \& Masi, 2013).

Resiliensi menurut Ungar (2008), mempunyai makna sebagai suatu kemampuan yang dimiliki oleh individu untuk mengatasi kesulitan yang dihadapi dan bagaimana melanjutkan perkembangannya dengan normal seperti semula. Seseorang yang mempunyai resiliensi akan mampu untuk secara cepat kembali kepada kondisi sebelum individu tersebut mengalami trauma, terlihat kebal dari berbagai peristiwa-peristiwa kehidupan yang negatif, serta mampu beradaptasi terhadap stres yang ekstrim dan kesengsaraan. Sedangkan Newcomb (La Framboise, 2006), memandang resiliensi sebagai suatu mekanisme perlindungan yang memodifikasi respon individu terhadap situasi-situasi yang beresiko pada titik-titik kritis disepanjang kehidupan individu.

Perspektif resiliensi menurut Lestari ( 2007), adalah memandang distress sebagai suatu tantangan bagi individu bukan sebagai hal yang merusak, juga melihat potensi yang dimiliki oleh individu untuk dapat berkembang dan melakukan perbaikan. Walsh (Lestari 2007), menjelaskan bahwa resileinsi merupakan kemampuan yang dimiliki oleh individu untuk dapat bangkit kembali dari penderitaan yang dialami, dengan menjadi lebih kuat serta lebih memiliki sumber daya; resiliensi bukar hanya sekedar kemampuan individu untuk bertahan, namun resiliensi lebih memampukan individu 
untuk bisa sembuh dari luka yang menyakitkan, mengendalikan kehidupannya dan kemudian mampu melanjutkan hidupnya dengan penuh semangat dan cinta kasih.

Resileinsi menurut Yumpi \& Satrio (2017) melibatkan adanya proses yang dinamis yang membantu individu dalam masalah yang signifikan. Reivich \& Shatte sulit (Taufiq, Susanty, Titi, \& Nurlina, 2014) mengartikan resiliensi sebagai kemampuan untuk beradaptasi dan tetap teguh dalam situasi. Holaday (1997) menyebutkan bahwa individu akan dianggap memiliki resiliensi yang baik apabila mampu secara cepat dapat kembali kepada kondisi sebelum trauma dan terlihat kebal dari berbagai macam peristiwa kehidupan yang negatif (Tampi, Kumaat, \& Masi, 2013).

Konsep resiliensi diungkapkan sebagai faktor penting untuk meraih keberlangsungan hidup. Resiliensi dibutuhkan setiap individu untuk menghadapi tantangan selama kehidupan berlangsung. Sehingga memungkinkan individu bisa mengatasi kesulitan hidup dan kembali pada kehidupannya secara normal (Setyowati, Hartati, \& Sawitri, 2010). Dalam hal ini resiliensi mempunyai peran yang sangat besar sebagai strategi dalam beradaptasi menghadapi perubahan iklim dan sebagai syarat yang pokok bagi komunitas untuk bangkit dari suatu bencana (Taufiq, Susanty, Titi, \& Nurlina, 2014).

Resiliensi dikatakan sebagai bentuk kesadaran yang dimiliki oleh individu untuk mengubah cara berpikirnya ketika menghadapi suatu masalah, sehingga individu tidak mudah putus asa. Artinya bahwa individu mampu beradaptasi atau menempatkan diri dengan baik terhadap kejadian hidup yang tidak menyenangkan. Salah contohnya yaitu mampu menghadapi permasalahan yang dialami. Dengan resiliensi yang dimiliki individu terdapat kecenderungan individu untuk menghadapi, mengatasi, bahkan keluar dari tekanan yang dialaminya. Sehingga individu yang memiliki resiliensi dapat mengurangi resiko negatif yang ditimbulkan dari kondisi sulit tersebut dan dapat hidup secara normal kembali. Setiap individu memiliki kemampuan untuk bangkit (resilien) secara alami, namun hal tersebut harus dipelihara dan diasah. Jika tidak, kemampuan tersebut dapat menghilang (Dewi, Djoenaina, \& Melisa, 2004).

Sarafino (Dewi, Djoenaina, \& Melisa, 2004) mengungkapkan bahwa individu yang memiliki resiliensi memiliki beberapa ciri-ciri yaitu :

a. Temperamennya cenderung yang lebih tenang, sehingga individu tersebut mampu menjalin hubungan dengan keluarga dan lingkungannya yang lebih baik lagi,

b. Memiliki kemampuan untuk bisa bangkit dengan cepat dari tekanan, stres, dan depresi.

Wolin \& Wolin (Setyowati, Hartati, \& Sawitri, 2010) menyebutkan bahwa resiliensi terdiri dari tujuh aspek utama yaitu :

a. Insight, merupakan kemampuan yang dimiliki seseorang untuk mampu memahami diri sendiri dan juga orang lain. Kemampuan ini juga mampu memberi arti dari sebuah situasi, sehingga individu dapat melakukan penyesuaian diri dengan berbagai situasi.

b. Kemandirian, adalah suatu kemampuan yang dimiliki oleh individu untuk bisa mengambil jarak secara emosional ataupun fisik dari yang menjadi sumber masalah sementara memenuhi tuntutan hati nurani.

c. Hubungan, merupakan suatu hubungan yang saling mendukung, saling jujur dan terbuka, serta berkualitas bagi kehidupan. Individu yang resilien memiliki hubungan yang intim dan memuaskan dengan orang lain.

d. Inisiatif, merupakan kemampuan untuk dapat mengambil alih kontrol atas masalah yang dihadapinya. Dimana individu mampu bersikap secara proaktif, bukan reaktif. Sehingga individu

4 P-ISSN 1907-8455 
tersebut dapat bertanggung jawab dalam memperbaiki diri sendiri, memecahkan masalah, dan mampu menghadapi masalah hal-hal yang tidak dapat diubah.

e. Kreatifitas, merupakan proses mental untuk menciptakan gagasan baru dalam menghadapi tantangan hidup. Individu mampu memikirkan berbagai pilihan yang ada, konsekuensi, dan juga alternatif dalam menghadapi suatu permasalahan.

f. Humor, merupakan kemampuan yang dimiliki individu guna mencari dan kemudian menemukan kegembiraan atau kebahagiaan dalam situasi apapun. Humor dapat membantu individu yang mengalami kesulitan, agar merasa lebih ringan.

g. Moralitas, merupakan suatu pengenalan dan pemahaman pada nilai-nilai yang ditandai dengan adanya keinginan untuk menjalani kehidupan dengan cara yang lebih baik dan produktif. Individu yang memiliki resiliensi baik mampu melakukan evaluasi pada berbagai hal dengan membuat keputusan secara tepat tanpa ada rasa takut pada pendapat orang lain. Individu tersebut juga bisa mengatasi kepentingan diri sendiri dalam memberikan bantuan kepada orang lain yang membutuhkan.

Neil (2006) mengungkapkan beberapa faktor yang dapat berperan dalam pengembangan resiliensi adalah dukungan sosial atau dukungan komunitas yang termasuk di dalamnya pengaruh budaya, dan dukungan personal (Fara, 2012). Holaday (1997) menjelaskan bahwa banyak factor yang mempengaruhi resiliensi, baik itu faktor internal yang meliputi keterampilan kognitif, sumber-sumber psikologis, maupun eksternal seperti dan dukungan sosial (Tampi, Kumaat, \& Masi, 2013).

Cobb (1976) berpendapat bahwa individu yang merasakan mendapatkan dukungan oleh lingkungan, akan membuatnya merasa segala sesuatu menjadi lebih mudah bagi individu, terutama ketika menghadapi kejadian-kejadian yang menegangkan (Lestari, 2007). Berdasarkan dari beberapa faktor yang terkait dengan terbentuknya resiliensi seseorang, ternyata penting untuk memperhitungkan dukungan sosial sebagai faktor yang berkaitan dengan tingkat resiliensi seseorang.

Dukungan sosial menurut Bastaman (1996) adalah sebagai hadiah yang diberikan kepada orangorang tertentu yang secara pribadi memberikan nasehat, motivasi, dan juga mengarahkan, dan memberikan semangat serta menunjukkan jalan keluar, pada saat individu sedang mengalami masalah dan juga mengalami kesulitan dalam melakukan kegiatan secara terarah untuk mencapai suatu tujuan (Tentama, 2014). Cobb (1976) menyatakan bahwa dukungan sosial dianggap sebagai perhatian, penghargaan, kenyamanan dan bantuan yang diterima oleh individu dari orang lain (Lestari, 2007). Orang lain di sini dapat diartikan sebagai individu perorangan ataupun kelompok.

Dukungan sosial menurut Maslikhah (2011), adalah merupakan salah satu istilah yang digunakan untuk menjelaskan bagaimana suatu hubungan sosial mampu memberi sumbangan yang bermanfaat untuk kesehatan mental ataupun kesehatan fisik individu. Dukungan sosial menurut Walen \& Lackman (2000), merupakan suatu pemikiran yang dirassakan oleh individu atass bentuk kepedulian yang diberikan oleh orang lain. Individu juga merasakan suatu pemahaman yang diberikan oleh jaringan sosial di sekitar individu. King (2010), memiliki pendapat, bahwa dukungan sosial merupan suatu umpan balik yang diberikan oleh individu kepada individu yang lain, dimana individu tersebut merupakan individu yang diperhatikan, dihormati, diberi penghargaan, dicintai dan dilibatkan dalam suatu jaringan sosial tertentu.

Spiegel, dkk (King, 2010), menjelasskan bahwa salah satu cara untuk memperoleh dukungan sosial dalam masa - masa yang sulit adalah dengan melakukan dan menjalin hubungan sosial dengan orang lain. Hubungan sosial yang dilakukan adalah dapat dalam bentuk berbagi sosial, yaitu dengan cara mau 
berbicara dengan orang lain yang mampu dan mau untuk berperan sebagai pendengar yang baik, serta mau memberikan saran dan nasehat. Individu yang berada dalam kelompok dengan disertai adanya dukungan dari lingkungan akan lebih dapat bertahan hidup dalam masa - masa yang sulit. Sarafino (Entezar, dkk, 2014), mendefinisikan dukungan sosial sebagai seberapa besar jumlah kebaikan, persahabatan, dan perhatian yang diberikan oleh anggota keluarga, teman dan juga orang lain.

Taylor (King, 2010), menjelaskan bahwa dukungan sosial dapat terbagi dalam tiga bentuk, yaitu:

a. Bantuan yang nyata, bantuan yang jelas - jelas diberikan oleh teman dan keluarga, kepada individu yang sedang mengalami situasi yang menekan. Bantuan yang diteria dapat berupa bantuan barang, yang bisa berwujud benda-benda yang bisa langsung digunakan, maupun bantuan jasa, yang bisa berbentuk pemberian motivasi, saran ataupun nasehat

b. Informasi, merupakan salah satu bentuk dukungan sosial yang diterima oleh individu, yang dapat berupa dengan cara memberikan saran mengenai tindakan bagaimana yang perlu dilakukan untuk mengatasi stresnya.

c. Dukungan emosional, merupakan dukungan yang bisa diberikan kepada individu yang sedang dalam kondisi tertekan. Tujuan dari pemberian dukungan emosional ini adalah untuk membuat individu yang sedang memiliki masalah merasakan lebih tenang, dan menghadapi stres yang dialaminya. Dukungan emosinal bisa dilakukan oleh keluarga ataupun teman, baik itu teman dalam sekolah ataupun teman sekerja. Dukungan emosional yang diberikan oleh keluarga ataupun tema bisa dalam bentuk rasa cinta, kasih sayang, rasa menghargai, serta penuh perhatian dan kepedulian kepada individu yang sedang mengalami masalah.

Sarafino (Huda, 2012) mengklasifikasikan lima bentuk dukungan sosial yang meliputi:

a. Dukungan emosional, suatu dukungan yang diberikan oleh individu dalam bentuk rasa empati, bentuk perhatian dan kepedulian terhadap individu yang bersangkutan. Dukungan emosional merupakan bentuk ekspresi dari afeksi, perhatian, kepercayaan, dan juga perasaan merasa didengarkan. Dukungan emosional bisa membuat seseorang merasa dirinya diterima, dipahami keberadaan dan keadaannya.

b. Dukungan penghargaan, merupakan dukungan atau penilaian yang positif, dorongan untuk maju, serta adanya perbandingan positif antara individu dengan individu lain. Melalui jenis dukungan ini, individu akan terbantu dimana dia merasakan dirinya mampu, berharga, dan dihargai.

c. Dukungan instrumental, mencakup bantuan yang diberikan secara langsung kepada individu. Bentuknya bisa berupa benda, jasa, waktu, atau uang. Dukungan instrumental membenrikan bantuan individu dalam menjalankan aktivitasnya serta memberikan bantuan individu untuk siap menghadapi sesuatu.

d. Dukungan informasional, dapat berupa memberikan nasehat, saran-saran, petunjuk-petunjuk, juga informasi maupun umpan balik. Dukungan informasional dapat membantu individu dalam mengatasi masalahnya dengan cara menambah wawasan yang lebih luas dan memberikan pemahaman kepada individu terhadap masalah yang dihadapi. Dukungan informasional juga dapat memberi arah bertindak dan inspirasi dalam menghadapi suatu hal.

e. Dukungan dari kelompok sosial, Dukungan jaringan sosial merupakan perasaan keanggotaan dalam suatu kelompok, untuk saling berbagi kesenangan dan aktivitas sosial. Sehingga individu merasa mempunyai orang yang senasib dengannya.

Rosenfeld, dkk (2000), menjelasskan bahwa individu mendapatkan dukungan sosial dari bererapa sumber, yaitu:

6 P-ISSN 1907-8455 
a. Orang tua, merupakan sumber dukungan sosial yang paling utama bagi seseorang. Dukungan sosial yang diberikan oleh orang tua adalah dukungan yang bersifat tidak menghakimi seseorang, namun lebih kepada dukungan yang bersedia untuk mendengarkan, memberikan dukungan emosional, memberikan penegasan atar kenyataan, dan bantuan pribadi. Dukungan emosional yang diberikan meliputi kenyamanan, kepedulian dan dukungan untuk selalu berada disisi individu yang membutuhkan dukungan tersebut. Orang tua memberikan penegasan atas kenyataan, hal tersebut mempunyai arti bahwa orang tua memberikan cara pandang yang sama untuk menyelesaikan masalah secara objektif.

b. Teman sebaya, merupakan sumber dukungan sosial yang dianggap memiliki hubungan sosial yang paling dekat di lingkungan individu. Dukungan sosial yang diberikan oleh teman sebaya lebih kepada dukungan emosional. Dukungan emosinal ini mampu meningkatkan efikasi diri individu untuk lebih mampu menyelesaikan permasalahan yang dihadapinya,

c. Pengajar, merupakan salah satu sumber dukungan sosial bagi individu yang berada dalam lingkup pendidikan. Pengajar dapat memberikan dukungan sosiak kepada individu dalam bentuk dukungan emosional dan dukungan penghargaan. Dukungan penghargaan yang diberikan oleh tenaga pengajar yaitu meliputi pengakuan serta menghargaan atas usaha usaha yang telah dilakukan oleh individu tersebut untuk menyelesaikan masalahnya.

King, dkk (Daalen, Sanders, \& Willemsen, 2005) mengelompokkan sumber dukungan sosial yaitu:

a. Relasi kerja

Dukungan sosial dapat diperoleh salah satunya bersumber dari relasi kerja seperti atasan dan rekan kerja individu. Individu yang bekerja pada suatu instansi atau kantor akan cenderung mendapat dukungan dari sumber tersebut.

b. Selain relasi kerja

Dukungan sosial juga dapat diperoleh individu dari sumber-sumber lain diluar dunia kerja individu. Sumber lain dari relasi kerja dapat diperoleh dari pasangan, keluarga, kerabat, ataupun teman-teman dan dari lingkungan disekitarnya.

Dukungan sosial mempunyai 3 fungsi utama (Huda, 2012) antara lain sebagai berikut:

a. Sumber daya atau mekanisme coping yang penting untuk mengurangi efek negatif dari stres dan konflik.

b. Meningkatkan kepuasan terhadap lingkungan yang memberikan dukungan sosial.

c. Menguntungkan bagi kesehatan mental dan fisik seseorang.

Kuncoro (Maharani, dkk, 2012), menjelaskan bahwa dukungan sosial merupakan informasi verbal ataupun non verbal, bentuk bantuan yang nyata atau tingkah laku yang diberikan oleh orang - orang terdekat dan yang akrap dengan individu di dalam lingkungan sosialnya, atau yang berupa kehadiran dan hal - hal yang dapat memberikan keuntungan emosinal atau memiliki pengaruh terhadap tingkah laku yang menerimanya. Dalam hal ini individu yang merasa mendapaatka dukungan sosial secara emosional akan merasakan perasaan lega karena merasa diperhatikan, mendapatkan atahan atau saran maupun kesan yang dirasa menyenangkan pada dirinya,

Kondisi traumatis menyebabkan individu membutuhkan resiliensi untuk dapat menyesuaikan diri dan tetap dapat melanjutkan kehidupan seperti sedia kala. Menurut Kumalasari \& Ahyani (2012) resiliensi dapat melindungi individu dari efek yang timbul dari peristiwa-peristiwa negatif. Individu yang mendapat dukungan oleh lingkungan maka segalanya akan terasa lebih mudah. Thoits 
mengartikan dukungan sosial sebagai tindakan bermanfaat yang dilakukan untuk individu oleh orang lain baik anggota keluarga, teman, dan orang lain yang berpengaruh (Achour \& Mohd Nor, 2014).

Dukungan sosial dibutuhkan individu agar dapat menjadi pribadi yang kuat dan dapat mengatasi setiap permasalahan hidup. Sehingga individu mampu mengurangi resiko-resiko negatif yang dapat merugikan dan mempengaruhi aktifitas hidup. Pengaruh dukungan sosial terhadap resiliensi individu yang bersangkutan sebaiknya perlu dijadikan pertimbangan yang penting. Individu yang mendapat dukungan sosial baik dari keluarga, teman atau lingkungannya akan lebih mampu menghadapi kesusahan atau kesulitan dibandingkan individu yang kurang menerima dukungan tersebut. Constance Loraine Lacy (2005) menemukan bahwa dukungan sosial mempunyai hubungan yang positif untuk resiliensi. Dukungan sosial menjadi faktor penting untuk membentuk resiliensi remaja Afrika Amerika. Selain itu Ariviyanti dan Pradoto (2014) juga menemukan bahwa terdapat tiga faktor yang paling berpengaruh dalam meningkatkan resiliensi masyarakat di kelurahan Tanjung Emas Semarang. Ketiga faktor tersebut adalah faktor peninggian rumah, peninggian jalan, dan adanya organisasi sosial tanggap bencana.

\section{METODE}

Penelitian ini merupakan penelitian kuantitatif korelasional. Populasi dalam penlitian ini adalah Populasi dalam penelitian ini adalah penyintas banjir rob kampung Tambak Lorok Semarang sebanyak 308 kepala keluarga yang berusia antara $20-70$ tahun. Adapun sampel penelitian ini berjumlah 161 . Variabel tergantung dalam penelitian ini adalah resiliensi dan variable bebasnya adalah dukungan social. Metode pengumpulan data penelitian ini menggunakan dua skala, yaitu skala resiliensi yang berjumlah 27 item, dengan daya beda item berkisar antara 0,258-0,539 dengan estimasi reliabilitas sebesar 0,802 . Skala yang kedua adalah skala dukungan social dengan item berjumlah 29 , daya beda item berkisar antara 0,313-0,619, adapun estimasi reliabilitas sebesar 0,908.

\section{HASIL}

Uji hipotesis dilakukan dengan menggunakan korelasi product moment dari Karl Pearson. Hasil uji hipotesis memperoleh skor $r_{x y}$ sebesar 0,428 dengan taraf signifikansi $p=0,000(p<0,01)$. Perolehan nilai tersebut menunjukkan bahwa terdapat hubungan positi yang signifikan antara dukungan sosial dengan resiliensi. Sehingga dapat dikatakan bahwa hipotesis yang diajukan peneliti diterima. Semakin besar dukungan sosial yang diterima para penyintas banjir rob Tambak Lorok maka semakin baik pula resiliensinya. Begitu juga sebaliknya, semakin kecil dukungan sosial yang diterima penyintas banjir rob Tambak Lorok maka semakin rendah pula resiliensinya.

\section{PEMBAHASAN}

Penelitian ini menggunakan analisis product moment untuk mengetahui adanya hubungan antara dukungan sosial dengan resiliensi pada penyintas banjir rob Tambak Lorok. Hasil analisis uji hipotesis pada penelitian ini memperoleh koefisien korelasi sebesar $r_{x y}=0,428$ dengan taraf signifikansi $p=0,000(p<0,01)$. Hal ini menunjukkan bahwa hipotesis penelitian ini diterima. Terdapat hubungan yang signifikan antara dukungan sosial dengan resiliensi. Artinya semakin besar dukungan sosial yang diterima para penyintas banjir rob Tambak Lorok maka semakin baik pula resiliensinya. Begitu pula sebaliknya, semakin kecil dukungan sosial yang diterima penyintas banjir rob Tambak Lorok maka semakin rendah pula resliensinya. Sumbangan efektif dukungan sosial terhadap resiliensi sebesar

8 P-ISSN 1907-8455 
$18,3 \%$ yang diperoleh dari R-square $=0,183 \times 100 \%$. Maka dapat diketahui setidaknya ada $81,7 \%$ faktor lain yang tidak diteliti oleh peneliti dan dapat berpengaruh pada resiliensi. Seperti dukungan personal, pengaruh budaya, sumber-sumber psikologis, maupun keterampilan kognitif.

Jaffee (Sippel, Pietrzak, Charney, Mayes, \& Southwick, 2015) menjelaskan tentang model transaksional resiliensi, dimana resiliensi yang baik diartikan sebagai interaksi antara karakteristik individu, keadaan hidup, dan konteks. Misalnya keluarga, masyarakat, dan budaya. Dalam hal ini dapat diartikan bahwa besarnya interaksi individu terhadap lingkungan disekitarnya dapat mempengaruhi resiliensi individu tersebut. Individu yang dapat mempertahankan interaksi sosial dilingkungannya dengan baik, akan mampu membantu dirinya memahami karakteristik diri sendiri dan orang lain. Sehingga individu dapat memahami seberapa banyak hal yang diperlukannya untuk berkomunikasi dan seberapa banyak ia mampu menangani berbagai macam situasi sulit yang dihadapi. Individu yang lebih mampu beradaptasi pada perubahan hidupnya yang terjadi secara tiba-tiba dapat dikatan sebagai individu yang resilien (Aprilia, 2013).

Hal ini sesuai dengan penelitian sebelumnya yang dilakukan oleh Chang \& Taormina pada tahun 2011 tentang Reduced Secondary Trauma among Chinese Earthquake Rescuers: A Test of Correlates and Life Indicators, menemukan bahwa dukungan sosial merupakan indikator terkuat atau terbesar terhadap resiliensi. Terutama dukungan jaringan sosial atau dukungan yang berasal dari orang disekitar (Sambu, 2015).

Dukungan yang diterima dapat menjadikan individu merasa bahwa dirinya disayangi. Menciptakan kondisi kenyamanan dan ketentraman yang membuat individu merasa siap dalam menjalani kehidupannya. Sehingga individu dapat berupaya untuk menghadapi permasalahan yang dialami secara kreatif (Everall, Altrows, \& Paulson, 2006).

$\mathrm{Li}$, Theng, dan Foo (2015) menjelaskan bahwa di dalam domain ilmu sosial, dikatakan peran dukungan sosial sebagai faktor resiliensi seseorang. Orang-orang yang mendapat dukungan sosial tinggi secara teoritis lebih mampu beradaptasi atau lebih mampu memodifikasi stres eksternal. Sehingga hal tersebut dapat meningkatkan penyesuaian yang lebih baik dan fun gsi psikososial. Apabila hal ini dikaitkan dengan penyintas banjir rob, maka individu yang mendapat dukungan dari keluarga, teman, atau orang dilingkungan sekitar akan lebih mampu menyesuaikan diri menghadapi kondisi sulit yang dialami. Individu dapat dengan mudah kembali pada kondisi awal sebelum terjadinya kesulitan. Serta individu akan lebih berani mengambil keputusan dalam menjalani kehidupan yang akan datang.

Dukungan sosial yang diterima oleh individu salah satunya adalah berasal dari keluarga. Yang pada akhirnya akan terjadilah resiliensi keluarga. Black dan Lobo (Yumpi \&Satrio, 2017) menjelaskan bahwa resiliensi keluarga merupakan proses adaptasi dan koping dalam keluarga sebagai suatu unit fungsional. Konsep resiliensi keluarga tidak hanya melibatkan individu atau anggota dalam keluarga sebagai symber daya potensial, namun lebih dari itu, meluas bahwa keluarga merupakan sebuah unit fungsional. Resiliensi keluarga melibatkan adanya potensi perubahan dan perkembangan, baik itu secara personal maupun relasional yang bisa membantu keluarga tersebut dari masalah. Keluarga akan dapat menjadi kuat serta lebih pandai ketikan menghadapi dengan masalah yang akan datang. Dengan adanya permasalahan yang dihadapi akan menjadikan kesempatan bagi keluarga tersebut untuk meninjau kembali prioritas, juga memberi stimulasi hubungan yang lebih baik serta tujuan dari hidup berkeluarga. Anggota keluarga mungkin juga bisa memperoleh dan menemukan atau bahkan mengembangkan hikmah serta kemungkinan cara mengatasi masalah yang baru. 
Taylor (King, 2010), menyatakan bahwa individu yang merasakan penderitaan secara emosional juga bisa menderita depresi, kecemasan dan kehilangan harga diri. Individu yang mengalami depresi akan mendaptkan ketenangan yang diperoleh dari keluarga dan teman yang menghargai dan mencintai individu tersebut. Hal ini dapat dijelaskan bahwa individu yang sedang mengalami musibah yang dalam penelitian ini adalah penyintas banjir rob, yang merasakan stres atau bahkan depresi, akan mudah bangkit dari keterpurukannya, atau akan lebih resilien, apabila penyintas banjir rob tersebut mendapatkan dukungan dari keluarga atau orang-orang sekitarnya.

\section{Gambar 1. Norma Kategorisasi Resiliensi}

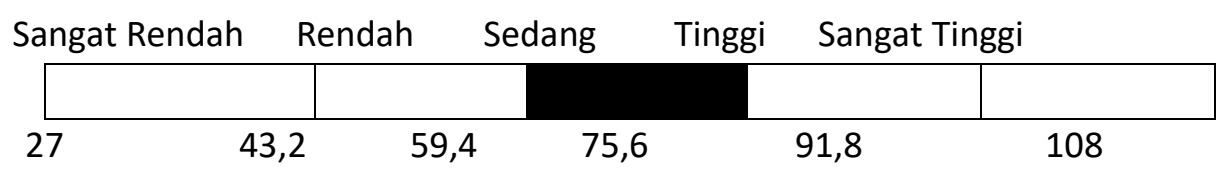

\section{Gambar 2. Norma Kategorisasi Dukungan Sosial}

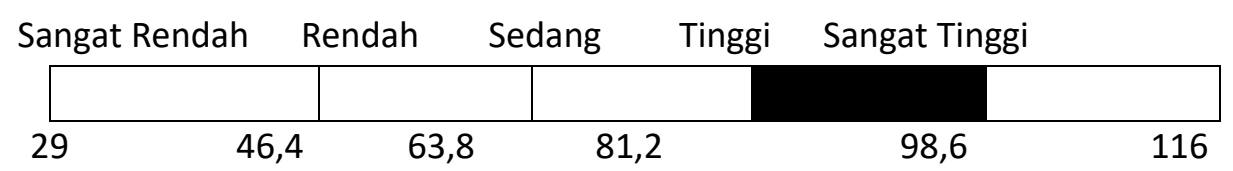

Dari hasil yang terlihat pada gambar 1 menunjukkan bahwa subjek penelitian rata - rata memiliki resiliensi yang sedang, hal ini menunjukkan bahwa subjek masih belum bisa sepenuhnya untuk segera bangkit dari keterpurukannya, setelah mengalami musibah, yaitu terkena banjir rob.

Hasil penelitian menunjukkan bahwa dukungan sosial yang diterima oleh subjek penelitian ini adalah tinggi, artinya subjek dalam penelitian ini mempersepsikan bahwa dirinya menerima dukungan sosial yang ditujukan kepadanya, baik dalam bentuk dukungan emosional, dukungan penghargaan, dukungan instrumental dan dukungan informassional serta dukungan dari kelompok sosial. Sedangkan tingkat reseliensi subjek dalam penelitian ini adalah dalam kategori sedang, artinya belum semua subjek dalam penelitian ini mampu dengan cepat untuk bangkit kembali ketika menghadapi permasalahan hidupnya, terutama saat rumahnya menjadi korban bajir akibat rob.

\section{KESIMPULAN}

Berdasarkan hasil analisis data dan pembahasan, menunjukkan bahwa dukungan sosial dan resiliensi memperoleh nilai $r_{x y}=0,428$ dengan taraf signifikansi $0,000(p<0,01)$.

Hasil analisis data tersebut menunjukkan bahwa ada hubungan positif yang signifikan antara dukungan sosial dengan resiliensi. Artinya bahwa semakin besar dukungan sosial yang diterima para penyintas banjir rob Tambak Lorok maka semakin baik pula resiliensinya. Begitu juga sebaliknya, semakin kecil dukungan sosial yang diterima penyintas banjir rob Tambak Lorok maka semakin rendah pula resiliensinya.

\section{SARAN}

\section{Bagi penyintas banjir rob}

Saran bagi para penyintas banjir rob yaitu agar dapat mempertahankan kegiatan-kegiatan positif yang telah ada dimasyarakat, seperti pengumpulan iuran untuk perbaikan jalan, gotong royong membersihkan lingkungan, dan kegiatan-kegiatan sosial lainnya. Serta para penyintas banjir 
rob juga harus tetap saling peduli selama masa-masa sulit akibat rob. Agar para penyintas tidak mudah putus asa dalam menjalani kehidupan.

\section{Bagi peneliti selanjutnya}

Saran bagi peneliti selanjutnya yaitu agar melakukan studi pendahuluan yang lebih mendalam mengenai resiliensi. Sehingga peneliti selanjutnya yang akan meneliti tentang resiliensi diharapkan dapat menghubungkannya denganfaktor-faktor lain yang ikut mempengaruhi. Seperti dukungan personal, pengaruh budaya, sumber-sumber psikologis, maupun keterampilan kognitif.

\section{DAFTAR PUSTAKA}

Achour, M., \& Mohd Nor, M. R. (2014, Januari). The Effects of Social Support and Resilience on Life Satisfaction of Secondary School Students. Journal of Academic and Applied Studies, Vol.4(No.1), 12-20.

Aprilia, W. (2013). Resiliensi dan dukungan sosial pada orang tua tunggal (studi kasus pada ibu tunggal di Samarinda). Ejournal Psikologi, Volume.1, 268-279.

Ariviyanti, N., \& Pradoto, W. (2014). Faktor-faktor yang meningkatkan resiliensi masyarakat dalam menghadapi bencana rob di kelurahan Tanjung Emas Semarang. Teknik Perencanaan dan Kota , vol.3, no.1, 993-1002.

Azwar, S. (2012). Metode penelitian. Yogyakarta: Pustaka Belajar.

Chandra K, R., \& Supriharjo, R. D. (2013). Mitigasi bencana banjir rob di Jakarta Utara. Jurnal Teknik Pomits, vol.2, no.1, C25-C30.

Dewi, F. I., Djoenaina, V., \& Melisa. (2004). Hubungan antara resiliensi dengan depresi pada perempuan pasca pengangkatan payudara (mastektomi). Jurnal Psikologi , vol.2 no.2, 101119.

Entezar, R. K., Othman, N., Kosnin, A. B., \& Ghanbaripanah, A. (2014). The relation between emotional intelligence, socisl support and mental health among Iranian and Malaysian mothers of mild intelligence disabled children. International journal of fondamental psychology and social sciences, 4 (1), 6 - 14.

Everall, R. D., Altrows, K. J., \& Paulson, B. L. (2006). Creating a future: a study of resilience in suicidal female adolescent. Journal of Counseling \& Development, vol.84, no.1, 461-470.

Fara, E. (2012, Juni). Resiliensi pada dewasa awal berlatar belakang budaya Aceh yang mengalami bencana tsunami 2004. Dipetik 13 Desember 2015, dari http://Lib.Ui.Ac.Id

Herusansono, W. (2012, Januari 25). Regional kompas. Dipetik 25 Oktober 2015, dari kompas.com: http://Regional.Kompas.Com

King, L. A. (2010). Psikologi umum: Sebuah pandangan apresiatif. (penterjemah : B. Marswendy). Jakarta: Salemba Humanika.

Lestari, K. (2007, November). Hubungan antara bentuk-bentuk dukungan sosial dengan tingkat resiliensi penyintas gempa di desa Canan, kecamatan Wedi, kabupaten Klaten. Dipetik 2 Mei 2015, dari Https://Core.Ac.Uk 
Li, J., Theng, Y. L., \& Foo, S. (2015). Does psychological resilience mediate the impact of social support on geriatric depression? An exploratory study among chinese older $\mathrm{n}$ exploratory study among chinese older. Asian Journal of Psychiatry, vol.4, 22-27.

Maharani. (2012). Hubungan dukungan sosial dengn konsep diri pada anak jalanan di rumah singgah sanggar alang alang surabaya. Jurnal keperawatan, 2 (1), 1 - 8.

Maslikhah, S. (2011). Studi tentang hubungan sosial, penyesuaian sosial di lingkungan sekolah dan prestasi akademik siswa SMIPIT Assyifa boarding school Subang Jawa Barat. Jurnal psikologi Undip, 10 (2), 103 - 114.

Miladan, N. (2009). Kajian kerentanan wilayah pesisir kota. Dipetik 9 Desember 2015, dari https://Core.Ac.Uk

Natalia, M., \& Alie, M. M. (2014). Kajian kemiskinan di kota Semarang (studi kasus: kampung nelayan Tambak Lorok). Teknik Perencanaan Wilayah dan Kota, Vol.3 (No.1), 51.

Sambu, L. J. (2015). Social support in promoting resilience among the internally displaced persons after trauma: a case of Kiambaa village in Uasin Gishu county, Kenya. British Journal of Psychology Research, vol.3, 23-34.

Sippel, L. M., Pietrzak, R. H., Charney, D. S., Mayes, L. C., \& Southwick, S. M. (2015). How does social support enhance resilience in the trauma-exposed individual? Ecology and Society, vol.20, no.10.

Somantri, L. (2008). Pemanfaatan teknik penginderaan jauh untuk mengidentifikasi kerentanan dan resiko banjir. Jurnal Gea , vol.8, nol.2, 1-6.

Tampi, B., Kumaat, L., \& Masi, G. (2013). Hubungan sikap dukungan sosial dengan tingkat resiliensi stres penyintas banjir di kelurahan Taas kecamatan Tikala kota Manado. Ejournal Keperawatan , vol.1, no.1, 1-8.

Taufiq, R., Susanty, E., Titi, D., \& Nurlina, E. (2014). Gambaranresiliensi anak pasca bencana banjir di desa Dayeuhkolot, kabupaten Bandung, Jawa Barat. Wacana Jurnal Psikologi , vol.6, no.11, 73-87.

Tentama, F. (2014). Dukungan sosial dan post-traumatic stress disorder pada remaja penyintas gunung merapi. Jurnal Psikologi Undip , vol.13, no.2, 133-138.

Ungar, M. (2008). Resilience across culture. British journal of social work, 38, $218-325$

Walen, H. R., \& Lachman, M. E. (2000). Social support and strain from partner family, and freids: Costs and benefits for men and women in adulthood. Journal of social support \& personal relationship. 17 (1), 5 - 30.

Yumpi, F. R., \& Satrio, D. W. (2017). Resilensi keluarga anak gangguan disintegrasi melalui konseling kelompok. Jurnal Insigth Fakultas Psikologi Universitas Muhammadiyah Jember, 13 (1), 11 25.

12 P-ISSN 1907-8455 